Jurnal Akuntansi Bisnis, Vol. 19, No. 2, September 2021

ISSN 1412-775X (media cetak) | 2541-5204 (media online)

\title{
Pengaruh Ukuran Perusahaan, Likuiditas, dan Perataan Laba Terhadap Kualitas Laba
}

\author{
Fifi Devi Yoanita ${ }^{1 *}$, Khairunnisa ${ }^{2}$ \\ ${ }^{1,2}$ Universitas Telkom \\ *Corresponding author email: fifideviyoanita@ student.telkomuniversity.ac.id
}

\begin{abstract}
Earnings is a component of financial statements that describes the level of profitability of a company. The earning information listed on the financial statements should be of quality because investors can use profits to assess the company's future performance. This research aims to determine the influence of company size, liquidity, and income smoothing on earning quality in transportation sub-sector companies listed on the Indonesia Stock Exchange for the period 20152019. To collect samples, this study uses purposive sampling which result in 45 firm observations. The data analysis technique used is multiple linear regression analysis. The results showed that company's size, liquidity, and income smoothing have significant positive effects on earning quality. In particular, the size of the company and income smoothing partially have significant positive effects on earning quality. Meanwhile, liquidity has no effect on earning quality.
\end{abstract}

Keywords: Earning Management, Earning Quality, Firm Size, Liqudity.

\begin{abstract}
Abstrak
Laba merupakan komponen laporan keuangan yang menggambarkan tingkat profitabilitas suatu perusahaan. Informasi laba yang tercantum pada laporan keuangan harus berkualitas karena investor dapat menggunakan laba untuk menilai kinerja perusahaan di masa depan. Penelitian ini bertujuan untuk mengetahui pengaruh ukuran perusahaan, likuiditas, dan perataan laba terhadap kualitas laba pada perusahaan sub sektor transportasi yang terdaftar di Bursa Efek Indonesia periode 2015-2019. Teknik sampling yang digunakan adalah teknik purposive sampling yang menghasilkan 45 observasi perusahaan. Teknik analisis data yang digunakan adalah analisis regresi linier berganda. Hasil dari penelitian ini menunjukkan bahwa ukuran perusahaan, likuiditas, dan perataan laba secara simultan berpengaruh positif signifikan terhadap kualitas laba. Secara parsial ukuran perusahaan dan perataan laba berpengaruh positif signifikan terhadap kualitas laba. Sementara itu likuiditas tidak berpengaruh terhadap kualitas laba.
\end{abstract}

\section{Kata Kunci: Kualitas Laba, Likuiditas, Perataan Laba, Ukuran Perusahaan.}

\section{PENDAHULUAN}

Laporan keuangan adalah suatu penyajian terstruktur dari posisi keuangan dan kinerja keuangan suatu entitas (PSAK No.1 (2019). Informasi pada laporan keuangan harus relevan, andal, dapat dibandingkan, dan mudah dipahami agar laporan keuangan tersebut dikatakan berkualitas. Soly dan Wijaya (2017) mengatakan bahwa informasi laba yang tercantum pada laporan keuangan harus berkualitas karena investor akan menggunakan laba untuk menilai kinerja perusahaan di 
masa depan. Karena itu, informasi yang terkandung dalam laporan keuangan harus mencerminkan keadaan keuangan perusahaan tanpa dilakukannya manipulasi laba.

Teori keagenan mengisyaratkan pentingnya pemisahan kepemilikan antara prinsipal dan agen (Octalianna dan Rahayuningsih, 2013). Hal ini dilakukan karena kedua belah pihak memiliki tujuan yang berbeda, sehingga menimbulkan sebuah konflik. Konflik yang terjadi akibat pemisahan kepemilikan disebut konflik keagenan atau agency conflict. Menurut Helina dan Permanasari (2017), tujuan manajer dalam menjalankan tugasnya adalah untuk mendapatkan imbalan atas kinerja yang sudah dilakukan untuk perusahaan, sedangkan investor bertujuan untuk mendapatkan return yang besar dari investasi yang dilakukan. Manajer merupakan pelaku organisasi yang lebih mengetahui seluruh informasi internal perusahaan dibandingkan dengan investor, sehingga manajer cenderung menyajikan informasi yang menguntungkan pihak manajemen dengan melakukan manipulasi laba dan menyebabkan asimetri informasi (Oktapiani dan Ruhiyat, 2019). Akibatnya, informasi pada laporan keuangan tidak dapat dijadikan sebagai acuan bagi investor dalam pengambilan keputusan. Jika laba yang dicantumkan pada laporan keuangan tidak sesuai dengan faktanya maka kualitas laba perusahaan tersebut perlu diragukan.

Salah satu perusahaan yang pernah melakukan manipulasi laba adalah PT Garuda indonesia pada tahun 2018. GIAA mengakui laba sebesar USD809,85 ribu. Akan tetapi, pada 2017 GIAA mengalami kerugian sebesar USD216,5 juta. Peningkatan laba dari 2017 - 2018 karena GIAA mengakui piutang dari PT. Mahata sebesar USD239,94 juta atau setara dengan Rp3,5 triliun sebagai pendapatan. Kenyataannya angka tersebut merupakan piutang yang dimiliki oleh PT. Mahata dan belum dibayar. Jika GIAA tidak mengakui piutang tersebut sebagai pendapatan, maka perusahaan akan mencatat kerugian sebesar USD213 juta (Pratiwi, 2019). Fenomena ini menunjukkan bahwa kecurangan dalam laporan keuangan dapat merugikan pihak eksternal yang menggunakan laporan keuangan sebagai dasar pengambilan keputusan. Pentingnya bagi pengguna laporan keuangan untuk mengetahui mengenai kualitas laba yang baik. Laba perusahaan dikatakan berkualitas jika laba yang disajikan dalam laporan keuangan dapat dipercaya menggambarkan kinerja perusahaan yang sebenarnya dan tidak dipengaruhi oleh kepentingan manajemen maupun investor. Kualitas laba adalah laba yang secara akurat menggambarkan profitabilitas operasional perusahaan (Sutopo, 2009). Kualitas laba dapat diukur menggunakan metode quality of earning ratio model Penman dengan pengukuran rasio dari arus kas operasi dibagi dengan laba bersih perusahaan (Septiyani et al., 2017). Penman dan Cohen, dalam Wati dan Putra (2017) menyebutkan bahwa kualitas laba yang baik dapat dijadikan prediksi pada laba masa yang akan datang dan arus kas operasi di masa yang akan datang. Kualitas laba yang dimilki perusahaan dikatakan baik, jika rasio yang dihasilkan semakin kecil.

Penelitian-penelian tentang kualitas laba telah banyak dilakukan di pasar modal Indonesia dan juga pasar modal asing. Berbagai faktor telah teridentifikasi mempengaruhi kualitas laba tetapi masih ada temuan-temuan yang tidak konsisten. Warianto dan Rusiti (2014) dan Setiawan (2017) memberi bukti adanya pengaruh positif ukuran perusahaan terhadap kualitas laba. Sebaliknya, Mauliddiyah (2020) dan Ginting (2017) gagal menemukan hubungan antara ukuran perusahaan dan kualitas laba. Setiawan (2017) melaporkan bahwa likuiditas perbengaruh negatif terhadap kualitas laba tetapi Warianto dan Rusiti (2014) menemukan hubungan positif antara likuiditas dan kualitas laba. Sementara Mauliddiyah (2020) tidak menemukan hubungan antara likuiditas dan kualitas laba. Berdasarkan pemikiran diatas, penelitian ini bertujuan menguji kembali pengaruh ukuran perusahaan dan likuiditas terhadap kualitas laba dengan tambahan satu variabel independen yaitu perataan laba. 
Jurnal Akuntansi Bisnis, Vol. 19, No. 2, September 2021

ISSN 1412-775X (media cetak) | 2541-5204 (media online)

\section{TINJAUAN LITERATUR DAN PERUMUSAN HIPOTESIS}

\section{Agency Theory}

Agency theory merupakan teori yang menjelaskan hubungan antara pihak eksternal dengan manajemen. Octalianna dan Rahayuningsih (2013) mengatakan bahwa diperlukannya pemisahan kepemilikan antara principal dan agent. Pemisahan kepemilikan dilakukan karena kedua belah pihak memiliki tujuan yang berbeda. Principal bertujuan untuk mendapatkan pengembalian yang besar atas investasi yang sudah dilakukan. Sedangkan, agent bertujuan untuk mendapatkan imbalan atas kinerja yang sudah dilakukan untuk perusahaan. Perbedaan tujuan tersebut dapat menyebabkan konflik, yaitu konflik keagenan atau agency conflict.

Konflik yang muncul akibat adanya pemisahan kepemilikan dapat mempengaruhi kualitas laba yang dilaporkan pada laporan keuangan karena manajer sebagai pelaku organisasi mengetahui seluruh informasi internal perusahaan secara detail dibandingkan pihak principal. Hal ini menyebabkan manajer akan menyajikan informasi yang menguntungkan dirinya sendiri dan dapat melakukan praktik manipulasi laba yang menyebabkan asimetri informasi (Oktapiani dan Ruhiyat, 2019). Asimetri informasi menyebabkan informasi pada laporan keuangan tidak bisa dijadikan dasar dalam pengambilan keputusan investasi oleh pihak investor.

\section{Kualitas Laba}

Menurut Irawati (2012) kualitas laba adalah laba dalam laporan keuangan yang mencerminkan kinerja keuangan perusahaan yang sesungguhnya. Bellovary et al (2005) dalam Helina \& Permanasari (2017) mengatakan bahwa kualitas laba sebagai kemampuan laba dalam merefleksikan kebenaran laba perusahaan dan membantu memprediksi laba mendatang, dengan mempertimbangkan stabilitas dan persistensi laba. Berdasarkan tiga definisi diatas, dapat disimpulkan bahwa kualitas laba adalah laba pada laporan keuangan yang menggambarkan kinerja keuangan sebenarnya dan dapat dijadikan prediksi laba di masa depan.

Laba perusahaan dikatakan berkualitas jika laba yang disajikan dalam laporan keuangan dapat dipercaya menggambarkan kinerja perusahaan yang sebenarnya dan tidak dipengaruhi oleh kepentingan manajemen maupun investor. Laba yang baik adalah laba yang dapat dijadikan prediksi di masa depan. Selain itu, menurut Abdelghany (2005) laba yang baik adalah laba yang dapat dijadikan prediksi dimasa depan.

\section{Ukuran Perusahaan}

Ukuran perusahaan menurut Brigham dan Houston dalam Warianto dan Rusiti (2014) adalah skala besar - kecilnya suatu perusahaan yang dapat diukur menggunakan jumlah tenaga kerja, tingkat penjualan, total hutang, dan total aset. Menurut Wati dan Putra (2017) ukuran perusahaan dibagi menjadi tiga kelompok, yaitu perusahaan kecil, perusahaan sedang, dan perusahaan besar. Dalam penelitian ini, total aset digunakan sebagai proksi untuk mengukur ukuran perusahaan karena perusahaan yang memiliki total aset besar cenderung lebih stabil dan dapat memaksimalkan kinerja perusahaan dalam menghasilkan laba, sehingga menjadi perhatian investor.

\section{Likuiditas}

Likuiditas adalah rasio yang digunakan untuk mengetahui kemampuan perusahaan dalam memenuhi kewajiban jangka pendeknya (Subramanyam dan Wild, 2010). Menurut Keown et al., (2018) likuiditas memiliki beberapa proksi seperti current ratio, quick ratio, average collection period, inventory turnover dan account receivable turnover.Kondisi keuangan perusahaan dapat dilihat pada nilai likuiditas. Perusahaan dengan nilai likuiditas yang tinggi maka kondisi keuangan 
Jurnal Akuntansi Bisnis, Vol. 19, No. 2, September 2021 ISSN 1412-775X (media cetak) | 2541-5204 (media online)

perusahaan tersebut dalam kondisi baik artinya, perusahaan mampu membayar kewajiban hutang jangka pendeknya kepada kreditur dengan tepat waktu. Pada penelitian ini, proksi yang digunakan untuk mengukur likuiditas adalah rasio cepat (acid-test/quick ratio). Rasio ini menggunakan aset lancar yang paling likuid dan tidak menggunakan persediaan ke dalam perhitungan quick ratio karena persediaan dianggap membutuhkan waktu untuk dikonversi menjadi kas.

\section{Perataan Laba}

Menurut Subramanyam dan Wild (2010) perataan laba merupakan praktik manajemen laba yang umum dilakukan dengan metode menurunkan atau menaikkan laba yang dilaporkan pada laporan keuangan untuk mengurangi fluktuasinya. Sedangkan, menurut Belkaoui (2006) perataan laba adalah pengurangan fluktuasi laba dari tahun ke tahun dengan memindahkan pendapatan dari tahun-tahun yang tinggi pendapatannya ke periode-periode yang kurang menguntungkan. Berdasarkan dua pengertian di atas, perataan laba dapat didefinisikan sebagai praktik manajemen laba dengan mengurangi fluktuasi labanya menggunakan cara menurunkan atau menaikkan labanya sehingga laba setiap tahunnya tidak terlalu bervariasi. Perataan laba boleh dilakukan karena termasuk dalam tindakan creative accounting yang memperhatikan kaidah akuntansi dalam penerapannya. Pada penelitian ini, indeks Eckel digunakan sebagai alat ukur perataan laba.

\section{Pengaruh Ukuran Perusahaan terhadap Kualitas Laba}

Menurut Warianto dan Rusiti (2014), Ukuran perusahaan menunjukkan besar dan kecilnya suatu perusahaan. pada penelitian ini, total aset digunakan sebagai alat ukur ukuran perusahaan karena perusahaan yang memiliki aset besar cenderung mampu menggunakan asetnya untuk menghasilkan laba yang besar dari kegiatan operasinya. Sehingga perusahaan tersebut tidak perlu melakukan manipulasi laba untuk menarik perhatian investor. Perusahaan besar lebih dipercayai oleh investor karena dianggap lebih stabil dan dapat meningkatkan kinerja perusahaannya dalam menghasilkan laba yang besar, sehingga tidak perlu melakukan praktik manajemen laba yang membuat kualitas laba menurun. Semakin besar ukuran suatu perusahaan, maka informasi yang dimiliki perusahaan lebih luas dan going concern perusahaan tersebut akan semakin tinggi sehingga investor lebih memiliki kepercayaan terhadap perusahaan besar dibandingkan perusahaan kecil (Ananda dan Ningsih, 2016). Sehingga semakin besar ukuran perusahaan maka kualitas labanya semakin baik. Hal ini sejalan dengan penelitian yang dilakukan oleh Ananda dan Ningsih (2016), Dira dan Astika (2014), dan Irawati (2012) yang menemukan bahwa ukuran perusahaan berpengaruh positif terhadap kualitas laba. Berdasarkan penjelasan diatas, hipotesis penelitian ini sebagai berikut:

\section{$H_{1}$ : Ukuran perusahaan berpengaruh positif signifikan terhadap kualitas laba.}

\section{Pengaruh Likuiditas terhadap Kualitas Laba}

Likuiditas merupakan rasio yang menggambarkan kemampuan perusahaan dalam memenuhi hutang jangka pendeknya (Subramanyam dan Wild, 2010:43). Pada penelitian ini, rasio likuiditas yang digunakan adalah quick ratio yang membandingkan aktiva paling lancar dengan hutang lancar. Apabila perusahaan memiliki nilai likuiditas yang tinggi maka perusahaan cenderung mampu dalam memenuhi kewajiban jangka pendeknya yang jatuh tempo. Artinya, perusahaan tersebut memiliki kinerja keuangan yang baik dalam memenuhi kewajiban jangka pendeknya dan tidak perlu melakukan manipulasi laba (Sukmawati, et al. 2014). Maka dari itu, semakin tinggi nilai likuiditas maka kualitas labanya semakin baik. Hal ini sejalan dengan penelitian yang dilakukan oleh Sukmawati et al (2014) dan Silfi (2016) yang mengatakan bahwa likuiditas 
Jurnal Akuntansi Bisnis, Vol. 19, No. 2, September 2021

ISSN 1412-775X (media cetak) | 2541-5204 (media online)

berpengaruh positif terhadap kualitas laba. Berdasarkan penjelasan diatas, hipotesis penelitian ini sebagai berikut:

$\mathrm{H}_{2}$ : Likuiditas berpengaruh positif signifikan terhadap kualitas laba.

\section{Pengaruh Perataan Laba terhadap Kualitas Laba}

Perataan laba merupakan bentuk praktik manajemen laba yang paling umum dilakukan. Metode perataan laba dilakukan dengan cara menurunkan dan menaikkan laba pada laporan keuangan untuk mengurangi fluktuasi laba agar tidak terlalu signifikan pertumbuhan dan penurunan labanya. Menurut Andalawestyas dan Ariyati (2019) perusahaan yang melakukan praktik perataan laba akan memiliki kualitas laba yang tinggi karena fluktuasi labanya tidak terlalu signifikan sehingga kinerja perusahaan terlihat baik dan stabil namun tetap pada batasan aturan yang ada. Sehingga perusahaan yang melakukan perataan laba maka kualitas labanya akan semakin baik. Hal ini sejalan dengan penelitian yang dilakukan oleh Andalawestyas dan Ariyati (2019) yang mengatakan bahwa perataan laba berpengaruh positif terhadap kualitas laba. Berdasarkan penjelasan diatas, hipotesis penelitian ini sebagai berikut:

$\mathrm{H}_{3}$ : Perataan laba berpengaruh positif signifikan terhadap kualitas laba.

\section{METODE PENELITIAN}

\section{Populasi dan Sampel}

Populasi penelitian ini adalah perusahaan sub sektor transportasi yang terdaftar di Bursa Efek Indonesia periode 2015-2019. Teknik sampling yang digunakan yaitu purposive sampling dengan kriteria tertentu dan menghasilkan 9 sampel perusahaan dengan 5 tahun periode sehingga memiliki 45 observasi perusahaan seperti yang dapat dilihat pada Tabel 1. Penelitian ini menggunakan metode kuantitatif karena menggunakan angka sebagai data dan metode statistik. Jenis data sekunder berupa laporan keuangan maupun tahunan masing-masing perusahaan yang dapat diakses melalui website Bursa Efek Indonesia maupun masing-masing perusahaan.

\section{Tabel 9. Prosedur Pengambilan Sampel}

\begin{tabular}{|c|l|c|}
\hline No & \multicolumn{1}{|c|}{ Kriteria } & Jumlah \\
\hline 1 & $\begin{array}{l}\text { Perusahaan sub sektor transportasi yang terdaftar di Bursa Efek } \\
\text { Indonesia tahun 2019. }\end{array}$ & 42 \\
\hline 2 & $\begin{array}{l}\text { Perusahaan yang tidak konsisten terdaftar sebagai sub sektor } \\
\text { transportasi pada Bursa Efek Indonesia periode 2015 - 2019. }\end{array}$ & $(17)$ \\
\hline 3 & $\begin{array}{l}\text { Perusahaan sub sektor transportasi yang tidak memiliki akhir } \\
\text { periode pelaporan keuangan 31 Desember. }\end{array}$ & $(1)$ \\
\hline 4 & $\begin{array}{l}\text { Perusahaan sub sektor transportasi yang tidak memiliki seluruh } \\
\text { komponen yang dibutuhkan sebagai data penelitian. }\end{array}$ & $(2)$ \\
\hline 5 & $\begin{array}{l}\text { Perusahaan sub sektor transportasi yang tidak memakai mata } \\
\text { uang rupiah pada laporan keuangan. }\end{array}$ & $(13)$ \\
\hline \multicolumn{2}{|l|}{ Total sampel yang menjadi objek penelitian. } & 9 \\
\hline \multicolumn{2}{|l|}{ Tahun penelitian 2015 - 2019. } & 45 \\
\hline \multicolumn{2}{|l|}{ Total data sampel yang dijadikan objek penelitian. } \\
\hline
\end{tabular}

Sumber: Data diolah penulis (2020) 
Jurnal Akuntansi Bisnis, Vol. 19, No. 2, September 2021

ISSN 1412-775X (media cetak) | 2541-5204 (media online)

\section{Definisi dan Pengukuran Variabel}

\section{Kualitas Laba}

Kualitas laba adalah laba dalam laporan keuangan yang mencerminkan kinerja keuangan perusahaan yang sesungguhnya. Kualitas laba diproksikan menggunakan metode Penman dengan persamaan sebagai berikut:

$$
\text { Earning Quality }=\frac{\text { Cash flow from operating activities }}{\text { Net Income }}
$$

Semakin rendah nilai yang dihasilkan, maka kualitas laba pada perusahaan tersebut semakin baik.

\section{Ukuran Perusahaan}

Ukuran perusahaan menurut Brigham dan Houston dalam Warianto dan Rusiti (2014) adalah skala besar - kecilnya suatu perusahaan yang dapat diukur menggunakan jumlah tenaga kerja, tingkat penjualan, total hutang, dan total aset. Ukuran perusahaan diproksikan menggunakan logaritma natural total aset dengan persamaan sebagai berikut:

\section{Likuiditas}

\section{Ukuran Perusahaan $=\operatorname{Ln} x$ Total Aset}

Likuiditas adalah rasio yang digunakan untuk mengetahui kemampuan perusahaan dalam memenuhi kewajiban jangka pendeknya (Subramanyam \& Wild, 2010:43). Likuiditas diproksikan menggunakan quick ratio dengan persamaan sebagai berikut:

$$
\text { Quick Ratio }=\frac{\text { aktiva lancar }- \text { persediaan }}{\text { hutang lancar }} \times 100 \%
$$

Nilai quick ratio yang tinggi menunjukkan likuiditas yang tinggi pula.

\section{Perataan Laba}

Income smoothing atau perataan laba adalah praktik manajemen laba yang dilakukan dengan metode menurunkan atau menaikkan laba yang dilaporkan pada laporan keuangan untuk mengurangi fluktuasinya. Income smoothing diproksikan menggunakan Indeks Eckel dengan persamaan sebagai berikut:

$$
\text { Indeks Eckel }=\frac{|C V \Delta I|}{|C V \Delta S|}
$$

Pada indeks Eckel, $C V \Delta I$ merupakan koefisien variasi dari laba dan $C V \Delta S$ merupakan koefisien variasi dari penjualan.

\section{Model regresi}

Hipotesis-hipotesis penelitian diuji menggunakan regresi berganda. Model yang digunakan adalah sebagai berikut:

$$
\mathrm{KL}=\beta 0+\beta 1 \mathrm{UP}+\beta 2 \mathrm{LK}+\beta 3 \mathrm{IS}+\mathrm{e}
$$

Keterangan: $\mathrm{KL}=$ Kualitas Laba, UP=Ukuran Perusahaan, $\mathrm{LK}=$ Likuiditas, dan $\mathrm{IS}=$ Perataan Laba.

\section{HASIL DAN PEMBAHASAN}

\section{Statistik Deskriptif}

Penelitian ini menguji pengaruh ukuran perusahaan, likuiditas, dan perataan laba terhadap kualitas laba dengan menggunakan 45 observasi perusahaan. Untuk melihat pola penyebaran data, Tabel 2 menyajikan statistik deskriptif untuk empat variabel yang digunakan dalam penelitian. Dari Tabel 2 dapat dilihat bahwa nilai minimum kualitas laba sebesar -13,29 yang diperoleh PT 
Jurnal Akuntansi Bisnis, Vol. 19, No. 2, September 2021 ISSN 1412-775X (media cetak) | 2541-5204 (media online)

Eka Sari Lorena Transport Tbk (LRNA) pada tahun 2015. Nilai maksimum kualitas laba sebesar 23,82 yang diperoleh PT Sidomulyo Selaras Tbk (SDMU). Pada tahun 2016 perusahaan sub sektor transportasi yang terdaftar di BEI periode 2015 sampai 2019 memiliki nilai rata-rata kualitas laba sebesar 2,38 dengan deviasi standar sebesar 6,55.

Tabel 10. Statistik Deskriptif

\begin{tabular}{|l|l|l|l|l|l|}
\hline \multicolumn{1}{|c|}{ 'Variabel } & N & Minimum & Maksimum & $\begin{array}{l}\text { Rata- } \\
\text { Rata }\end{array}$ & $\begin{array}{l}\text { Std. } \\
\text { Dev. }\end{array}$ \\
\hline Kualitas Laba (KL) & 45 & $-13,29$ & 23,82 & 2,38 & 6,55 \\
\hline Ukuran Perusahaan (UP) & 45 & 26,11 & 29,64 & 27,55 & 1,21 \\
\hline Likuiditas (LK) & 45 & 0,25 & 5,55 & 1,49 & 1,49 \\
\hline Perataan Laba (IS) & 45 & 0,14 & 1,92 & 0,86 & 0,47 \\
\hline
\end{tabular}

Sumber: Data diolah penulis (2021)

Dari Tabel 2 dapat diketahui nilai minimum ukuran perusahaan sebesar 26,11 yang diperoleh PT Sidomulyo Selaras Tbk (SDMU) pada tahun 2019. Nilai maksimum ukuran perusahaan pada periode 2015-2019 sebesar 29,64 yang diperoleh PT Blue Bird Tbk (BIRD) tahun 2019. Nilai ratarata pada periode 2015-2019 sebesar 27,55 sebanyak 26 unit sampel memiliki ukuran perusahaan dibawah rata-rata dan 19 unit sampel diatas rata-rata. Sampel penelitian ini memiliki nilai standar deviasi sebesar 1,21 dari nilai rata-ratanya.

Nilai minimum likuiditas sebesar 0,248 yang diperoleh PT WEHA Transportasi Indonesia Tbk (WEHA) pada tahun 2015. Nilai maksimum likuiditas sebesar 5,55 yang diperoleh PT Pelayaran Nelly Dwi Putri Tbk (NELY) pada tahun 2017. Nilai rata-rata likuiditas sebesar 1,49. Ini menunjukkan bahwa perusahaan sampel memiliki likuiditas yang baik. Dari 45 unit sampel terdapat 31 unit sampel memiliki nilai likuiditas dibawah rata-rata dan 14 unit sampel memiliki nilai likuiditas diatas rata-rata. Sampel penelitian ini memiliki nilai standar deviasi sebesar 1,49 dari nilai rata-ratanya. Sementara itu, nilai minimum manajemen laba sebesar 0,14 yang diperoleh PT Adi Sarana Armada Tbk (ASSA). Nilai maksimum manajemen laba sebesar 1,92 diperoleh PT WEHA Transportasi Indonesia Tbk (WEHA). Nilai rata-rata manajemen laba sebesar 0,86 dengan deviasi sebesar 0,47 .

\section{Uji Asumsi Klasik}

Tabel 3 menyajikan hasil uji asumsi klasik. Uji normalitas dilakukan dengan metode Skewness dan Kurtosis menunjukkan nilai ZSkewness dan ZKurtosis terletak diantara -1,96 sampai 1,96 dengan nilai signifikansi 0,05 yaitu -1,858 dan 0,252. Hal ini menunjukkan bahwa data penelitian ini berdistribusi normal. uji multikolinearitas menunjukkan bahwa tidak ada variabel independen yang memiliki nilai tolerance. lebih dari 0,10 dan nilai VIF kurang dari 10. Hal ini menunjukkan bahwa tidak terjadi gejala multikolinearitas antar masing-masing variabel pada penelitian ini. Uji autokorelasi dilakukan dengan metode Durbin Watson menunjukkan nilai 1,773 dan nilai $d$ terletak diantara dU dan 4-dU yaitu 1,6597 < 1,773 < 2,3403. Hal ini menunjukkan bahwa tidak terjadi autokorelasi pada penelitian ini. Uji heteroskedasitas dilakukan dengan uji Glejser dengan hasil tidak ada satupun variabel yang memiliki nilai signifikansi kurang dari 0,05 sehingga tidak terjadi heteroskedastisitas pada penelitian ini. 
Jurnal Akuntansi Bisnis, Vol. 19, No. 2, September 2021 ISSN 1412-775X (media cetak) | 2541-5204 (media online)

Tabel 11. Hasil Uji Asumsi Klasik

\begin{tabular}{|l|c|l|c|c|c|c|}
\hline \multirow{2}{*}{ Variabel } & \multicolumn{2}{|c|}{ Uji Normalitas } & \multicolumn{2}{c|}{$\begin{array}{c}\text { Uji } \\
\text { Multikolinearitas }\end{array}$} & $\begin{array}{c}\text { Uji } \\
\text { Autokorelasi }\end{array}$ & $\begin{array}{c}\text { Uji } \\
\text { Heteroskedastisitas }\end{array}$ \\
\cline { 2 - 7 } & ZSkewness & ZKurtosis & Tolerance & VIF & $\begin{array}{c}\text { Durbin } \\
\text { Watson }\end{array}$ & Sig. \\
\hline & $-1,858$ & 0,252 & & & 1,773 & 0,194 \\
\hline $\begin{array}{l}\text { Kualitas } \\
\text { Laba }\end{array}$ & & & & & & 0,244 \\
\hline $\begin{array}{l}\text { Ukuran } \\
\text { Perusahaan }\end{array}$ & & & 0,691 & 1,447 & & 0,354 \\
\hline Likuiditas & & & 0,843 & 1,186 & & 0,992 \\
\hline $\begin{array}{l}\text { Perataan } \\
\text { Laba }\end{array}$ & & & 0,710 & 1,409 & & \\
\hline
\end{tabular}

Sumber: Data yang diolah (2021)

\section{Hasil Uji Hipotesis}

Tabel 4 menyajikan hasil pengujian hipotesis menggunakan analisis regresi. Dari Tabel 4 dapat dilihat bahwa ukuran perusahaan yang diukur menggunakan logaritma natural total aset memiliki pengaruh positif terhadap kualitas laba dengan nilai signifikansi sebesar 0.01 yang lebih kecil dari 0.05. Hal ini menunjukkan bahwa semakin besar ukuran perusahaan, maka semakin tinggi pula kualitas laba. Dengan demikian H1 diterima.

Tabel 4. Hasil Uji Regresi

\begin{tabular}{|l|l|l|l|l|l|}
\hline \multirow{2}{*}{ Model } & \multicolumn{2}{|c|}{$\begin{array}{c}\text { Unstandardized } \\
\text { Coefficients }\end{array}$} & $\begin{array}{c}\text { Standardized } \\
\text { Coefficients }\end{array}$ & \multirow{2}{*}{$\mathrm{t}$} & \multirow{2}{*}{ Sig. } \\
\cline { 2 - 6 } & $\mathrm{B}$ & Std. Error & Beta & & \\
\hline (Constant) & $-27,617$ & 7,225 & & $-3,823$ & 0,001 \\
\hline UP & 0,932 & 0,241 & 0,781 & 3,865 & 0,001 \\
\hline LK & 0,659 & 0,332 & 0,363 & 1,986 & 0,061 \\
\hline IS & 2,068 & 0,858 & 0,481 & 2,411 & 0,026 \\
\hline Adj $\mathrm{R}^{2}=0,352$ & \multicolumn{5}{|l}{} \\
\hline
\end{tabular}

Sumber: Data diolah penulis (2021)

Dari Tabel 4 juga dapat dilihat bahwa, variabel likuiditas yang diukur menggunakan quick ratio tidak memiliki pengaruh terhadap kualitas laba dengan nilai signifikansi sebesar 0,061 yang lebih lebih besar dari 0.05. Dengan demikian, H2 ditolak. Sementara itu, perataan laba yang diukur menggunakan indeks Eckel memiliki pengaruh positif terhadap kualitas laba dengan nilai signifikansi sebesar 0.026. Ini menunjukkan bahwa semakin tinggi perataan laba, semakin tinggi pula kualitas laba. Dengan demikian, H3 diterima.

Koefisien determinasi (Adj. $\mathrm{R}^{2}$ ) digunakan untuk mengukur seberapa jauh kemampuan model dalam menerangkan variasi variabel dependen (Ghozali, 2018:97). Berdasarkan Tabel 4, nilai Adj. $\mathrm{R}^{2}$ yang diperoleh adalah sebesar 0,352. Hal ini menunjukkan bahwa variabel independen yaitu ukuran perusahaan, liabilitas, dan perataan laba dapat menjelaskan variabel dependen yaitu kualitas laba sebesar 35,2\% sedangkan sisanya 64,8\% dapat dijelaskan oleh variabel independen lainnya yang tidak digunakan pada penelitian ini. 


\section{Pengaruh Ukuran Perusahaan Terhadap Kualitas Laba}

Berdasarkan hasil pengujian yang sudah dilakukan, ditemukan bawah variabel ukuran perusahaan yang diproksikan dengan logaritma natural total aset berpengaruh positif signifikan terhadap kualitas laba, sehinggi H1 diterima. Hal ini sejalan dengan penelitian yang dilakukan oleh Ananda dan Ningsih (2016), Dira dan Astika (2014), dan Irawati (2012). Perusahaan yang berukuran besar cenderung memiliki nilai aset yang besar. Apabila perusahaan memiliki nilai aset yang besar maka perusahaan tersebut dapat menggunakan asetnya untuk kegiatan operasi perusahaan dalam menghasilkan laba yang besar dan kinerja perusahaan dinilai baik. Sehingga, perusahaan tersebut tidak perlu melakukan praktik manipulasi laba pada laporan keuangannya agar laporan keuangan terlihat menarik bagi pihak investor untuk berinvestasi pada perusahaan tersebut.

\section{Pengaruh Likuiditas Terhadap Kualitas Laba}

Berdasarkan hasil pengujian yang sudah dilakukan, ditemukan bahwa variabel likuiditas yang diproksikan dengan quick ratio tidak berpengaruh terhadap kualitas laba, sehingga $\mathrm{H} 2$ ditolak. Penelitian ini sejalan dengan penelitian yang dilakukan oleh Soly dan Wijaya (2017) yang menyatakan bahwa likuiditas tidak berpengaruh terhadap kualitas laba. Perusahaan yang memiliki nilai likuiditas yang tinggi cenderung belum dinilai belum optimal dalam mengelola aset lancarnya untuk melakukan operasi bisnis, pembiayaan, maupun investasi sehingga kinerja perusahaannya kurang baik. Untuk meningkatkan kinerja perusahaan, akan timbulnya keinginan untuk melakukan praktik manipulasi laba yang dilakukan oleh pihak manajemen agar laba pada laporan keuangan terlihat cantik agar terlihat menarik perhatian bagi pinak eksternal untuk berinvestasi. Hal ini menunjukkan bahwa nilai likuiditas yant ginggi tidak menjamin bahwa kualitas laba perusahaan tersebut baik.

\section{Pengaruh Perataan Laba terhadap Kualitas Laba}

Berdasarkan hasil pengujian yang sudah dilakukan, ditemukan bahwa income smoothing yang diproksikan dengan Indeks Eckel berpengaruh positif signifikan terhadap kualitas laba, sehingga H3 diterima. Penelitian ini sejalan dengan penelitian yang dilakukan oleh Andalawestyas dan Ariyati (2019) yang menyatakan bahwa perataan laba berpengaruh positif signifikan terhadap kualitas laba. Perusahaan yang melakukan praktik income smoothing cenderung memiliki fluktuasi laba yang lebih stabil setiap tahunnya sehingga kinerja keuangan perusahaan dinilai stabil. Selain itu, praktik perataan laba yang dilakukan tetap menggunakan kaidah akuntansi yang berlaku sehingga tidak melanggar kaidah yang berlaku.

\section{SIMPULAN}

Laba yang berkualitas adalah laba yang mampu mencerminkan realitas ekonomik yang dialami perusahaan dalam periode tertentu. Investor membutuhkan laba yang berkualitas untuk menilai prospek perusahaan di masa mendatang. Berbagai penelitian telah dilakukan untuk mengidentifikasi faktor-faktor yang berpengaruh terhadap kualitas laba. Namun hasil yang ditemukan belum konklusif dan beberapa temuan saling bertentangan khususnya untuk variabel ukuran perusahaan dan likuiditas. Karena ini, penelitian ini dilakukan untuk menguji kembali pengaruh ukuran perusahaan dan likuiditas terhadap kualitas laba dengan menambah satu variabel indepenenden yaitu perataan laba. Berdasarkan hasil pengujian yang sudah dilakukan, didapatkan kesimpulan bahwa secara simultan ukuran perusahaan, likuiditas, dan perataan laba berpengaruh positif signifikan terhadap kualitas laba. Secara parsial ukuran perusahaan dan perataan laba 
Jurnal Akuntansi Bisnis, Vol. 19, No. 2, September 2021 ISSN 1412-775X (media cetak) | 2541-5204 (media online)

berpengaruh positif signifikan terhadap kualitas laba. Sementara itu, likuiditas tidak berpengaruh terhadap kualitas laba. Untuk peneliti selanjutnya yang akan melakukan penelitian mengenai kualitas laba disarankan untuk menggunakan variabel yang diduga mempengaruhi kualitas laba seperti profitabilitas, struktur modal, dan good corporate governance. Selain itu dapat menggunakan objek dan periode penelitian yang berbeda.

\section{DAFTAR PUSTAKA}

Abdelghany, K. E. 2005. Measuring The Quality of Earnings. Managerial Auditing Joutnal Vol.20 (9), 1001-1015.

Ananda, R., dan E. S. Ningsih. 2016. Pengaruh Likuiditas, Kepemilikan Institusional, dan Ukuran Perusahaan Terhadap Kualitas Laba (Pada Perusahaan Manufaktur yang Terdaftar di Bursa Efek Indonesia Tahun 2010-2014). Jurnal Ilmiah Mahasiswa Ekonomi Akuntansi (JIMEKA), 1(2), 277-294.

Andalawestyas, M., dan T. Ariyati. 2019. Dampak Perataan Laba Terhadap Kualitas Laba dengan Kualitas Audit Sebbagai Variabel Moderasi. Jurnal Akuntansi dan Keuangan Methodist Vol.2(2), 154-163.

Dira, K. P., dan I. O. Astika. 2014. Pengaruh Struktur Modal, Likuiditas, Pertumbuhan Laba, dan Ukuran Perusahaan Pada Kualitas Laba. E-Jurnal Akuntansi Universitas Udayana, 7(1), 64-78.

Ghozali, I. 2018. Aplikasi Analisis Multivariate dengan Program IBM SPSS 25. Semarang: Badan Penerbit Universitas Diponegoro.

Ginting, S. 2017. Pengaruh Profitabilitas, Likuiditas, dan Ukuran Perusahaan Terhadap Kualitas Laba Pada Perusahaan Manufaktur yang Terdaftar Di Bursa Efek Indonesia. Jurnal Wira Ekonomi Mikroskil, 7 (2): 227-236.

Helina, dan M. Permanasari. 2017. Faktor Faktor Yang Mempengaruhi Kualitas Laba Pada Perusahaan Publik Manufaktur. Jurnal Bisnis dan Akuntansi Vol.19(1a), 325-334.

Irawati, D. E. 2012. Pengaruh Struktur Modal, Pertumbuhan Laba, Ukuran Perusahaan dan Likuiditas Terhadap Kualitas Laba. Accounting Analysis Journal Vol.1 No.2, 1-6.

Keown, A. J., S. Titman, dan J. D. Martin. 2018. Financial Management Principles and Application (13th ed). Newyork: Pearson.

Nadirsyah, dan F. N. Muharram, 2015. Stuktur Modal, Good Corporate Governance, dan Kualitas Laba. Jurnal Dinamika Akuntansi dan Bisnis 2(2), 184-198.

Octalianna, dan D. A. Rahayuningsih. 2013. Analisis Kepemilikan Managerial Berbasis pada Teori Keagenan. Jurnal Bisnis dan Akuntansi 15(1), 65-72.

Oktapiani, K., dan E. Ruhiyat, 2019. Kualitas Laba: Investment Opportunity Set Dan Komite Audit. Jurnal Ilmiah Akuntansi Universitas Pamulang 7(2), 173-188. 
Jurnal Akuntansi Bisnis, Vol. 19, No. 2, September 2021 ISSN 1412-775X (media cetak) | 2541-5204 (media online)

Septiyani, G., E. Rasyid, dan E. G. Tobing. 2017. Faktor-Faktor yang Mempengaruhi Kualitas Laba Pada Perusahaan Industri Dasar dan Kimia yang Terdaftar di Bursa Efek Indonesia Periode 2012-2015. Fundamental Management Journal Online Vol. 2 (1), 70-79.

Setiawan, B. R. Pengaruh Ukuran Perusahaan, Profitabilitas, Likuiditas, Dan Leverage Terhadap Kualitas Laba Pada Perusahaan Manufaktur Industri Barang Konsumsi Yang Terdaftar Di BEI. Jurnal Penelitian dan Kajian Ilmiah, 11 (77).

Silfi, A. 2016. Pengaruh Pertumbuhan Laba, Struktur Modal, Likuiditas, dan Komite Audit Terhadap Kualitas Laba. Jurnal Valuta Vol.2 (1), 17-26.

Soly, N., dan N. Wijaya. 2017. Faktor-Faktor Yang Mempengaruhi Kualitas Laba Pada Perusahaan Manufaktur. Jurnal Bisnis dan Akuntansi Vol.19(1), 47-55.

Subramanyam, K. R., dan J. J. Wild. 2010. Analisis Laporan Keuangan Edisi 10 Buku 1. Jakarta: Penerbit Salemba Empat.

Sukmawati, S., Kusmuriyanto, dan L. Agustina. 2014. Pengaruh Struktur Modal, Ukuran Perusahaan, Likuiditas, dan Return On Asset Terhadap Kualitas Laba. Accounting Analysis Journal Vol.3(1), 26-33.

Sutopo, B. 2009. Manajemen Laba dan Manfaat Kualitas Laba dalam Keputusan Investasi. Jurnal Akuntansi Universitas Sebelas Maret.

Triani, A. 2017. Creative Accounting Sebagai Informasi yang Baik atau Menyesatkan? AKRUAL: Jurnal Akuntansi Vol.8 (2), 103-111.

Warianto, P., dan C. Rusiti. 2014. Pengaruh Ukuran Perusahaan, Struktur Modal, Likuiditas, dan Investment Opportunity Set (IOS) Terhadap Kualitas Laba Pada Perusahaan manufaktur yang Terdaftar di BEI. MODUS Vol.26 (1), 19-32.

Wati, G. P., dan I. Putra. 2017. Pengaruh Ukuran Perusahaan, Leverage, dan Good Corporate Governance pada Kualitas Laba. E-Jurnal Akuntansi Universitas Udayana Vol.19(1), 137167. 